\title{
Production of Nuclear Polyhedrosis Virus of Anticarsia gemmatalis Hübner (Lepidoptera:Noctuidae): Effect of Vírus Dosage, Host Density and Age
}

\author{
Flávio Moscardi ${ }^{1}$, Luiz G. Leite ${ }^{2}$ and Carlos E. Zamataro ${ }^{1}$ \\ ${ }^{1}$ EMBRAPA/CNPSo, Caixa postal 231, 86001-970, Londrina, PR. \\ ${ }^{2}$ Instituto Biológico, Seção de Controle Biológico de Pragas, Rod. Heitor \\ Penteado Km 3,5-Jardim Palmeiras, 13001-970, Campinas, SP.
}

An. Soc. Entomol. Brasil 26(1): 121-132 (1997)

Produção do Vírus de Poliedrose Nuclear de Anticarsia gemmatalis Hübner (Lepidoptera:Noctuidae): Efeito da Dose do Patógeno,

População e Idade do Hospedeiro

RESUMO - A produção do vírus de poliedrose nuclear (VPN) de Anticarsia gemmatalis Hübner em laboratório foi avaliada para lagartas de 1,0, 1,5, 2,0 e $2,5 \mathrm{~cm}$ inoculadas com duas doses do vírus $\left(10^{6}\right.$ e $10^{7}$ corpos poliédricos de inclusão-CPI/ml), pulverizadas sobre a dieta artificial do inseto. As larvas inoculadas com 2,0 cm, na maior dose, proporcionaram os maiores rendimentos na produção do VPN. No entanto, as perdas foram elevadas $(42,4 \%$ a $64,0 \%)$, devido ao canibalismo, mortes por outras causas e sobrevivência à infecção. Num outro experimento foram utilizadas duas doses do VPN $\left(1,0 \times 10^{7}\right.$ e 4,0 x $\left.10^{7} \mathrm{CPI} / \mathrm{ml}\right)$, três densidades de lagartas/copo $\left(25,20\right.$ e 15), inoculadas no início do $4^{\circ}$ instar (I4L); final do $4^{\circ}$ instar (F4L); inicio do $5^{\circ}$ instar (I5L) e final do $5^{\circ}$ instar (F5L). A maior produção do VPN ocorreu para I5L, com 25 lagartas por copo, em ambas as doses, com uma eficiência em tomo de $90 \%$, a despeito da diminuição do número de CPI/lagarta e o aumento do canibalismo com o incremento na densidade de lagartas/copo.

PALAVRAS-CHAVE: Insecta, lagarta-da-soja, baculovirus.

ABSTRACT - The laboratory production of Anticarsia gemmatalis Hübner nuclear polyhedrosis virus (AgNPV) was evaluated for larvae inoculated at 1.0, $1.5,2.0$, and $2.5 \mathrm{~cm}$ and with two NPV dosages, $10^{6}$ and $10^{7}$ polyhedron inclusion bodies (PIB)/ml, sprayed on the insect diet surface. A fixed population of 25 larvae/300-ml cup was used. Highest virus yield was achieved for larvae inoculated with ca. $2.0 \mathrm{~cm}$ at the higher NPV dosage. Losses of NPV-inoculated larvae ranged from $42.4 \%$ to $64 \%$, due to high incidence of canibalism, death by other causes, and pupation. In another experiment, larvae were inoculated with two NPV dosages $\left(1.0 \times 10^{7}\right.$ and $\left.4.0 \times 10^{7} \mathrm{PIB} / \mathrm{ml}\right)$, using 25,20 , and 15 larvae/cup at the beginning of 4th instar (B4L); end of 4th instar (E4L); beginning of 5th instar (B5L); and end of 5th instar (E5L). Highest NPV production was attained for B5L at 25 larvae/cup, for both dosages, with a production efficiency of ca $90 \%$, in spite of a decrease in PIB/larva and an increase in canibalism with the increase in larval density. Better standardization of larvae at inoculation improved efficiency in NPV production.

KEY WORDS: Insecta, velvetbean caterpillar, baculovirus. 
The use of viruses as microbial insecticides depends on the development of largescale virus production methods. Despite the advances in multiplying nuclear polyhedrosis (NP V) and granulosis (GV) viruses "in vitro", this method still has technical and economical limitations that prevent its use at commercial level (Shieh 1989, Federici 1990). The "in vivo" production of viruses experienced considerable progress with the improvement of insect rearing techniques (Shapiro 1986), allowing the commercialization of viral insecticides, such as the NPV of Heliothis (Helicoverpa) spp. (Ignoffo \& Couch 1981), the NPV of Lymantria díspar L. (Hüber 1986), and the GV of Cydia pomonella L. (Hüber 1990). For the "in vivo" production of viruses, host tissues should be used as efficiently as possible to obtain the maximum yield of biologically active virus per insect or recipient (Ignoffo 1966, Shapiro 1986). Significant losses of virus may occur due to canibalism, death by other microoganisms, and insect survival to pupal stage, among other factors, as a result of unproper climatic conditions, insect density/recipient, larval size or instar at inoculation, virus dosage, etc (Shapiro 1986).

In Brazil, a NPV of the velvetbean caterpillar, Anticarsia gemmatalis Hübner (AgNPV), has been extensively employed as a microbial insecticide in soybean (Moscardi 1986,1989), with the annual treated área reaching ca. 1,000,000 ha. (Moscardi 1990, Moscardi \& Sosa-Gomez 1992, 1993). The production of the AgNPV has been mainly based on its multiplication on natural host populations, for further processing of dead larvae into a wettable-powder formulation (Moscardi 1989). Although of very low cost, the amount of AgNPV produced in the field varies considerably from season to season due to climatic conditions and incidence of natural mortality factors, which influence larval abundance. Therefore, development of effective laboratory production methods of the AgNPV is necessary for its multiplication all year long and complement field-produced NPV.
Techniques for laboratory rearing of A gemmatalis were developed (Greene et al. 1976, Hoffmann-Campo et al. 1985, Parra et al. 1993). However, attempts to produce the AgNPV in the laboratory by private companies were not cost effective. Therefore, this study was conducted to evaluate AgNPV production as related to the dose of inoculium, density of host larvae/recipient, and larval size or instar at the moment of inoculation by the NPV

\section{Material and Methods}

A. gemmatalis larvae were obtained from a colony established at CNPSo-EMBRAPA from larvae collected in the region of Londrina, Paraná, and maintained on artificial diet (Hoffmann-Campo et al. 1985). The AgNPV isolate (LD-79) was obtained in 1979 from naturally-infected A. gemmatalis larvae in a soybean field near Londrina. This isolate is routinely produced for use as a microbial insecticide in Brazil (Moscardi 1989). It was multiplied in 4th instar A. gemmatalis larvae by feeding the insects with artificial diet sprayed in the surface with a viral suspension containing $10^{7}$ polyhedron inclusion bodies (PIB)/ $\mathrm{ml}$. Dead larvae were collected daily and stored at $-18^{\circ} \mathrm{C}$ for partial purification of PIB. Larvae were homogenized in a blender in distilled water + sodium dodecil sulfate (SDS) at $0.01 \%$ and filtered through four layers of cheese cloth. The filtrate was centrifuged at 1,500 rpm for two minutes and the resulting supernatant was centrifuged at 7,000 rpm for 20 minutes. This sequence of centrifugation was repeated three times and the final pellet was suspended in distiled water. Number of PIB was quantified in a counting chamber (Brightline Hemocitometer).

One experiment was conducted with larvae of ca. 1.0, 1.5, 2.0, and $2.5 \mathrm{~cm}$ (density of $25 / 300$-cardboard cup) inoculated with two AgNPV dosages $\left(10^{6}\right.$ and $\left.10^{7} \mathrm{PIB} / \mathrm{ml}\right)$, sprayed (DeVilbiss hand sprayer) upon the diet surface. The second experiment consisted of two viral dosages $\left(1.0 \times 10^{7}\right.$ and $\left.4.0 \times 10^{7} \mathrm{PIB} / \mathrm{ml}\right)$ three larval populations per cup $(15,20$ and 25 ), inoculated at four phases of larval deve- 
lopment: beginning of fourth instar (B4L), end of fourth instar (E4L), beginning of fifth instar (B5L), and end of fifth instar (E5L). Each treatment consisted of five cups, replicated four times. As the viral suspension dried on the diet surface, the larvae were transferred to the cups and maintained at room temperature (26$29^{\circ} \mathrm{C}$ ). Evaluations on larval mortality were made daily up to pupation. NPV-dead larvae were weighted and stored at $-18^{\circ} \mathrm{C}$ for further determination of PIB/larva/cup. A completely randomized design was used, and the means compared by the Duncan's test $(\mathrm{P}<0.05)$. Evaluated parameters were number of larvae killed by N P V, by other microorganisms, and by canibalism, number of larvae surviving to the pupal stage, weight of NPV-dead larvae, number of PIB/larva, and number of PIB/ recipient.

\section{Results}

Experiment 1. The average number of AgNPV-dead larvae per cup was significantly higher for insects inoculated with $2.0 \mathrm{~cm}$ at $10^{7} \mathrm{PIB} / \mathrm{ml}$ (Table 1). However, at this combination, only $57.6 \%$ of the larvae died by the AgNPV Total losses in AgNPV production ranged from $42.4 \%$ to $64.0 \%$, mainly due to canibalism and other causes (eg. bacteria), and to a lesser extent to insect pupation. The canibalism occurred either on alive larvae, weakened by NPV infection, or on freshly dead larvae, being higher among insects inoculated with 1.0 and $1.5 \mathrm{~cm}$. At the lower dosage there was a clear and inverse relationship between increase in larval size at inoculation and canibalism. Fosses due to mortality by other causes ranged from 5.9 (23.6\%) to 7.7 larvae $(30.8 \%)$, at the lower dosage, with no significant differences found among the distinct larval sizes. At the higher dosage, they varied from $16.8 \%$ to $29.6 \%$, being significantly higher among larvae infected with $2.5 \mathrm{~cm}$. Losses due to pupation tended to be higher with the increase in larval size at inoculation. The increase in dosage did not result in a significative reduction in pupation, except for larvae infected with $2.0 \mathrm{~cm}$. In gen-
Table 1. Number of larvae dead by different causes and of pupae obtained after inoculation of Anticarsia geminatalis at four larval sizes with two dosages of its NPV Initial larval population was 25 per $300-\mathrm{ml}$ cup.

\begin{tabular}{llr}
\hline Larval & \multicolumn{1}{c}{ NPV Dosage in PIB/ml } \\
\cline { 2 - 2 } size $(\mathrm{cm})$ & $1.0 \times 10^{6}$ & $1.0 \times 10^{7}$ \\
\hline
\end{tabular}

Number of NPV-dead larvae/cup'

$\begin{array}{lllllll}1.0 & 9.7 & \mathrm{bc} & \mathrm{A} & 10.9 & \mathrm{~b} & \mathrm{~A} \\ 1.5 & 9.0 & \mathrm{c} & \mathrm{A} & 10.8 & \mathrm{~b} & \mathrm{~A} \\ 2.0 & 12.3 & \mathrm{a} & \mathrm{A} & 14.4 & \mathrm{a} & \mathrm{B} \\ 2.5 & 11.2 & \mathrm{ab} & \mathrm{A} & 11.3 & \mathrm{~b} & \mathrm{~A}\end{array}$

Number of larvae dead by canibalism ${ }^{1}$

$\begin{array}{lllllll}1.0 & 7.9 & \mathrm{a} & \mathrm{A} & 8.4 & \mathrm{a} & \mathrm{A} \\ 1.5 & 6.1 & \mathrm{~b} & \mathrm{~A} & 6.0 & \mathrm{~b} & \mathrm{~A} \\ 2.0 & 3.4 & \mathrm{c} & \mathrm{A} & 3.7 & \mathrm{c} & \mathrm{A} \\ 2.5 & 2.2 & \mathrm{~d} & \mathrm{~A} & 3.6 & \mathrm{c} & \mathrm{B}\end{array}$

Number of larvae dead by other causes ${ }^{\prime}$

$\begin{array}{lllll}1.0 & 5.9 & \mathrm{a} & \mathrm{A} & 4.6 \mathrm{~b} \text { A } \\ 1.5 & 7.1 \mathrm{a} & \mathrm{A} & 6.1 \mathrm{ab} \mathrm{A} \\ 2.0 & 6.0 \mathrm{a} & \mathrm{A} & 4.2 \mathrm{~b} \text { A } \\ 2.5 & 7.7 \mathrm{a} & \mathrm{A} & 7.4 \mathrm{a} A\end{array}$

Number of pupae ${ }^{1}$

\begin{tabular}{lllllll}
1.0 & 1.7 & $\mathrm{c}$ & $\mathrm{A}$ & 1.1 & $\mathrm{~b}$ & $\mathrm{~A}$ \\
1.5 & 2.8 & $\mathrm{~b}$ & $\mathrm{~A}$ & 2.1 & $\mathrm{a}$ & $\mathrm{A}$ \\
2.0 & 3.3 & $\mathrm{ab}$ & $\mathrm{A}$ & 2.7 & $\mathrm{a}$ & $\mathrm{A}$ \\
2.5 & 3.9 & $\mathrm{a}$ & $\mathrm{B}$ & 2.7 & $\mathrm{a}$ & $\mathrm{A}$ \\
\hline
\end{tabular}

${ }^{1}$ Means followed by same lower case letter, in the columns, or by same upper case letter, in the lines, are not different by the Duncan's test $(\mathrm{P} \leq 0.05)$. Coefficients of variation $(\mathrm{CV})$, from top to botton, were $12.9,11.7,31.4$, and $32.2 \%$, respectively.

eral, the evaluated parameters were highly influenced by the larval size at inoculation $(\mathrm{P}<0.05)$.

Larvae infected with $2.0 \mathrm{~cm}$, at the higher dosage $\left(10^{7} \mathrm{PIB} / \mathrm{ml}\right)$, provided the highest NPV 
Table 2. Weight of NPV-dead larvae and number of polyhedron inclusion bodies (PIB) per 300-ml cup obtained after inoculation of Anticarsia gemmatalis at four larval sizes with two NPV dosages. Initial larval population was 25 per 300-ml cup.

\begin{tabular}{|c|c|c|}
\hline \multirow{2}{*}{$\begin{array}{l}\text { Larval } \\
\text { Size }(\mathrm{cm})\end{array}$} & \multicolumn{2}{|c|}{ NPV dosage in PIB/ml } \\
\hline & $1.0 \times 10^{6}$ & $1.0 \times 10^{7}$ \\
\hline \multicolumn{3}{|c|}{ Weight $(g)$ of NPV-dead larvae/cup' } \\
\hline 1.0 & $1.39 \mathrm{~b} \quad \mathrm{~A}$ & $1.67 \mathrm{c} \mathrm{A}$ \\
\hline 1.5 & 1.38 b A & 1.73 c B \\
\hline 2.0 & 2.19 a A & 2.74 a $B$ \\
\hline 2.5 & 2.05 a A & $2.06 \mathrm{~b} \quad \mathrm{~A}$ \\
\hline \multicolumn{3}{|c|}{ Number of PIB $\times 10^{10} / \mathrm{cup}^{1}$} \\
\hline 1.0 & $1.64 \mathrm{~b}$ A & $2.16 \mathrm{~b} \quad \mathrm{~A}$ \\
\hline 1.5 & $1.91 \mathrm{~b} \mathrm{~A}$ & $2.51 \mathrm{~b} \quad \mathrm{~A}$ \\
\hline 2.0 & 2.79 a A & 3.81 a $B$ \\
\hline 2.5 & $2.21 \mathrm{ab} \mathrm{A}$ & $2.64 \mathrm{~b} \quad \mathrm{~A}$ \\
\hline
\end{tabular}

${ }^{1}$ Means followed by same lower case letter, in the columns, or by same upper case letter, in the lines, are not different by the Duncan's test $(\mathrm{P} \leq 0.05)$. Coefficients of variation $(\mathrm{CV})$, from top to botton, were 13.3 and $22.5 \%$, respectively.

production, considering weight of dead larvae and PIB/cup (Table 2). The mean number of $\mathrm{PIB} /$ larva increased as size at inoculation increased, reaching a peak for larvae infected with $2.0 \mathrm{~cm}$, and decreasing for those inoculated with $2.5 \mathrm{~cm}$ (Fig. 1). Observed values

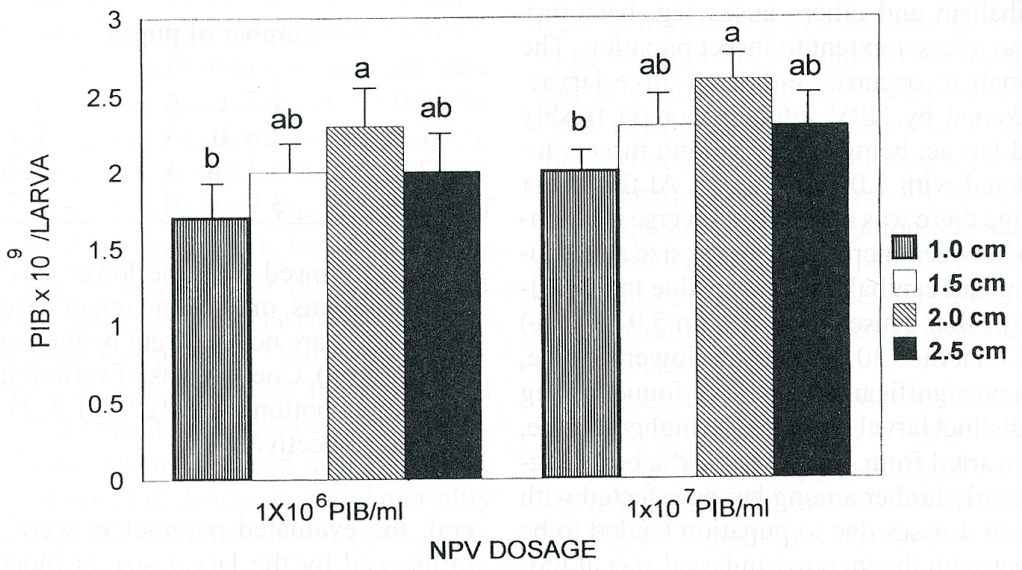

Figure 1. Mean number of polyhedron inclusion bodies (PIB)/larva ( \pm SEM), obtained by inoculation of larvae of Anticarsia gemmatalis of different sizes $(1.0,1.5,2.0$, and $2.5 \mathrm{~cm}$ ) with two NPV dosages. 
varied from $1.69 \times 10^{9}\left(1.0-\mathrm{cm}\right.$ larvae) to $2.27 \times 10^{9}$ PIB/larva (2.0-cm larvae) at the lower dosage, and from $1.98 \times 10^{9}\left(1.0-\mathrm{cm}\right.$ larvae) to $2.65 \times 10^{9}$ PIB/larva (2.0-cm larvae) at the higher dosage. These results, in conjunction with those in Table 1, help explain the higher NPV production for larvae inoculated with $2.0 \mathrm{~cm}$.

Experiment 2. In this trial a bether standardization of larvae at inoculation was sought, by selecting the insects by instar rather than by approximate size. The mean number of NPVdead larvae per cup was significantly higher for larvae inoculated as early 5th instar (B5L) at 25 larvae/cup, for both NPV dosages (Table 3 ). In these conditions, $89.2 \%$ to $90.0 \%$ of the larvae died by NPV As larval density was reduced, there was a clear trend of lower numbers of AgNPV-dead larvae/cup, although the highest efficiency (96.7\%) in AgNPV-dead larvae production was obtained for B4L at 15 larvae/cup, at the higher dosage.

Lower losses of NPV-dead larvae occurred for those inoculated as B4L or B5L, at 25 larvae/cup (Tables 4 - 6). On the other hand, the losses, except by pupation, tended to decrease as larval density/cup was reduced, mainly for E4L and E5L, probably due to a lower competition for food at lower densities. Canibalism was significantly higher among E4L, at $1.0 \times 10^{7}$ $\mathrm{PIB} / \mathrm{ml}$ and 25 larvae/cup, decreasing at lower densities (Table 4). At 4.0x $10^{7} \mathrm{PIB} / \mathrm{ml}$ caniba-

Table 3. Number of NPV-dead larvae obtained after inoculation of Anticarsia gemmatalis at four larval development stages and three populations per 300-ml cup, with two NPV dosages.

\begin{tabular}{|c|c|c|c|}
\hline \multirow{3}{*}{$\begin{array}{l}\text { Larval } \\
\text { Development }\end{array}$} & \multicolumn{3}{|c|}{ Number of NPV-dead larvae/cup } \\
\hline & \multicolumn{3}{|c|}{ Larval population /cup } \\
\hline & 25 & 20 & 15 \\
\hline & \multicolumn{3}{|c|}{ Dosage $=1.0 \times 10^{7} \mathrm{PIB} / \mathrm{ml}^{1}$} \\
\hline $\begin{array}{l}\text { Beginning of } \\
4 \text { th instar }\end{array}$ & 21.7 a $\mathrm{A}$ & $17.5 \mathrm{a} \mathrm{B}$ & $12.5 \mathrm{aC}$ \\
\hline $\begin{array}{l}\text { End of } 4 \text { th } \\
\text { instar }\end{array}$ & $15.7 \mathrm{~b} \mathrm{~A}$ & $14.5 \mathrm{~b} \mathrm{~A}$ & $9.0 \mathrm{~b} \mathrm{~B}$ \\
\hline $\begin{array}{l}\text { Beginning of } \\
5 \text { th instar }\end{array}$ & 22.3 a $\mathrm{A}$ & $15.9 \mathrm{ab} B$ & $12.0 \mathrm{a} \mathrm{C}$ \\
\hline \multirow[t]{2}{*}{$\begin{array}{l}\text { End of } 5 \text { th } \\
\text { instar }\end{array}$} & $12.6 \mathrm{c} \mathrm{A}$ & $11.3 \mathrm{c} \mathrm{A}$ & $6.9 \mathrm{c} \mathrm{B}$ \\
\hline & \multicolumn{3}{|c|}{ Dosage $=4.0 \times 10^{7} \mathrm{PIB} / \mathrm{ml}^{1}$} \\
\hline $\begin{array}{l}\text { Beginning of } \\
\text { 4th instar }\end{array}$ & 22.3 a $\mathrm{A}$ & $18.2 \mathrm{a} \mathrm{B}$ & 14.5 a C \\
\hline $\begin{array}{l}\text { End of 4th } \\
\text { instar }\end{array}$ & $19.3 \mathrm{~b} \mathrm{~A}$ & 15.5 b B & $11.9 \mathrm{~b} \mathrm{C}$ \\
\hline $\begin{array}{l}\text { Beginning of } \\
5 \text { th instar }\end{array}$ & 22.5 a $\mathrm{A}$ & 18.1 a B & $12.7 \mathrm{abC}$ \\
\hline $\begin{array}{l}\text { End of 5th } \\
\text { instar }\end{array}$ & $13.0 \mathrm{c} \mathrm{A}$ & $12.6 \mathrm{c} \mathrm{A}$ & $9.4 \mathrm{c} \mathrm{B}$ \\
\hline
\end{tabular}

${ }^{1}$ Means followed by same lower case letter, in the columns, or by same upper case letter, in the lines, are not different by the Duncan's test $(\mathrm{P} \leq 0.05)$. Coefficients of variation $(\mathrm{CV})$, from top to botton, were 5.22 and $6.32 \%$, respectively. 
Table 4. Mean number of larvae dead by canibalism after inoculation of Anticarsia gemmatalis at four larval development stages and three populations per 300-ml cup, with two NPVdosages.

\begin{tabular}{|c|c|c|c|}
\hline \multirow{3}{*}{$\begin{array}{l}\text { Larval } \\
\text { Development }\end{array}$} & \multicolumn{3}{|c|}{ Number of larvae dead by canibalism/cup } \\
\hline & \multicolumn{3}{|c|}{ Population of larvae/cup } \\
\hline & 25 & 20 & 15 \\
\hline & \multicolumn{3}{|c|}{ Dosage $=1.0 \times 10^{7} \mathrm{PIB} / \mathrm{ml}^{1}$} \\
\hline $\begin{array}{l}\text { Beginning of } \\
4 \text { th instar }\end{array}$ & $1.81 \mathrm{~b} \mathrm{~A}$ & $1.23 \mathrm{a} \mathrm{A}$ & 1.34 a $\mathrm{A}$ \\
\hline $\begin{array}{l}\text { End of 4th } \\
\text { instar }\end{array}$ & $3.53 \mathrm{a} \mathrm{A}$ & $1.87 \mathrm{a} \mathrm{B}$ & 0.59 a $\mathrm{C}$ \\
\hline $\begin{array}{l}\text { Beginning of } \\
5 \text { th instar }\end{array}$ & $1.14 \mathrm{~b} \mathrm{~A}$ & 0.92 a A & 0.61 a $\mathrm{A}$ \\
\hline \multirow[t]{2}{*}{$\begin{array}{l}\text { End of } 5 \text { th } \\
\text { instar }\end{array}$} & $1.77 \mathrm{~b} \mathrm{~A}$ & $1.36 \mathrm{a} \mathrm{A}$ & 0.69 a $\mathrm{A}$ \\
\hline & \multicolumn{3}{|c|}{ Dosage $=4.0 \times 10^{7} \mathrm{PIB} / \mathrm{ml}^{1}$} \\
\hline $\begin{array}{l}\text { Beginning of } \\
\text { 4th instar }\end{array}$ & $2.65 \mathrm{ab} \mathrm{A}$ & $1.25 \mathrm{ab} \mathrm{AB}$ & 0.43 a B \\
\hline $\begin{array}{l}\text { End of 4th } \\
\text { instar }\end{array}$ & $3.56 \mathrm{a} \mathrm{A}$ & $1.67 \mathrm{ab} \mathrm{B}$ & 0.60 a B \\
\hline $\begin{array}{l}\text { Beginning of } \\
5 \text { th instar }\end{array}$ & $1.54 \mathrm{~b} \mathrm{~A}$ & $0.73 \mathrm{~b} \mathrm{~A}$ & 0.72 a $\mathrm{A}$ \\
\hline $\begin{array}{l}\text { End of } 5 \text { th } \\
\text { instar }\end{array}$ & 3.85 a $\mathrm{A}$ & $2.35 \mathrm{a} \mathrm{AB}$ & 1.36 a B \\
\hline
\end{tabular}

${ }^{1}$ Means followed by same lower case letter, in the columns, or by same upper case letter, in the lines, are not different by the Duncan's test $(\mathrm{P} \leq 0.05)$. Coefficients of variation $(\mathrm{CV})$, from top to botton, were 25.9 and $26.4 \%$, respectively.

lism was significantly lower among B5L at 25 larvae/cup, with highest values observed for E4L and E5L. The average number of deaths by other causes (Table 5) was also significantly higher for E4L and E5L, at the higher dose and larval population/cup. Similarly to the canibalism, this factor induced lower losses at lower larval densities. The increase in dosage led to a substantial decrease in the mortality by other causes, except for E5L at 25 larvae/ cup, with losses varying from zero (B4L) to $18.4 \%$ (E5L). Losses due to pupation were low for B4L and B5L, moderate for $\mathrm{E} 4 \mathrm{~L}$, and high for E5L (Table 6). For E5L, at the lower NPV dosage, losses represented 33.2\%, 30.5\%, and $43.3 \%$, respectively at 25,20 , and 15 larvae per cup, compared to $2.4 \%, 9.0 \%$, and $10.7 \%$ for B5L. Therefore, insect pupation was generally higher at lower larval densities/cup, and decreased with the increment in NPV dosage. 
Table 5. Mean number of larvae dead by other causes after inoculation of Anticarsia gemmatalis at four larval development stages and three populations per 300-ml cup, with two NPV dosages.

Larval

Number of larvae dead by other causes/cup

Development

Population of larvae/cup

25

20

15

$$
\text { Dosage }=1.0 \times 10^{7} \mathrm{PIB} / \mathrm{ml}^{1}
$$

$\begin{array}{lccc}\begin{array}{l}\text { Beginning of } \\ 4 \text { th instar }\end{array} & 0.1 \mathrm{c} \mathrm{A} & 0.2 \mathrm{a} \mathrm{A} & 0.2 \mathrm{a} \mathrm{A} \\ \begin{array}{l}\text { End of 4th } \\ \text { instar } \\ \text { Beginning of }\end{array} & 3.9 \mathrm{a} \mathrm{A} & 0.7 \mathrm{a} \mathrm{B} & 0.8 \mathrm{a} \mathrm{B} \\ \begin{array}{l}5 \text { th instar } \\ \text { End of } 5 \text { th } \\ \text { instar }\end{array} & 0.8 \mathrm{c} \mathrm{A} & 1.0 \mathrm{aA} & 0.6 \mathrm{a} \mathrm{A} \\ & 2.2 \mathrm{~b} \mathrm{~A} & 1.2 \mathrm{a} \mathrm{AB} & 0.8 \mathrm{a} \mathrm{B}\end{array}$

Dosage $=4.0 \times 10^{7} \mathrm{PIB} / \mathrm{ml}^{2}$

\begin{tabular}{lccc}
$\begin{array}{l}\text { Beginning of } \\
\text { 4th instar }\end{array}$ & 0.0 & 0.2 & 0.0 \\
$\begin{array}{l}\text { End of 4th } \\
\text { instar }\end{array}$ & 0.7 & 0.4 & 0.1 \\
$\begin{array}{l}\text { Beginning of } \\
\text { th instar }\end{array}$ & 0.3 & 0.5 & 0.5 \\
$\begin{array}{l}\text { End of 5th } \\
\text { instar }\end{array}$ & 4.6 & 0.6 & 0.3 \\
\hline
\end{tabular}

${ }^{1}$ Means followed by same lower case letter, in the columns, or by same upper case letter, in the lines, were not different by the Duncan's test $(\mathrm{P} \leq 0.05)$. Coefficient of variation $(\mathrm{CV})$ was $25.9 \%$ for the lower dosage.

${ }^{2}$ For the higher dosage there was no homogeneity of variances.

The mean weight of AgNPV-dead larvae/ cup (Table 7) was significantly higher for B5L at 25 larvae/cup, decreasing with the reduction in the initial number of larvae/recipient. Although E5L had a greater body length (ca. $2.5 \mathrm{~cm}$ ) at inoculation, they resulted in the lowest weight of NPV-dead larvae per cup, because of high incidence of canibalism, mortality by other causes, and pupation (Tables 4 - 6). At the lower NPV dosage losses totalled
$49.1 \%$ for $\mathrm{E} 5 \mathrm{~L}$ as opposed to $10 \%$ for $\mathrm{B} 5 \mathrm{~L}$. On the other hand, B4L had low levels of losses, but resulted in mean weights of NPV-dead larvae/cup similar to those observed for E5L, due to the smaller size and lower weight of individual $\mathrm{B} 4 \mathrm{~L}$ at death. The mean number of PIB per cup (Table 8) followed a similar trend, since it is strongly correlated to the larval weight at death (F. Moscardi, unpublished data). At 25 larvae/cup the NPV production 
Table 6. Mean number of pupae obtained after inoculation of Anticarsia gemmatalis larvae at four larval development stages and three populations per 300-ml cup, with two NPV dosages.

\begin{tabular}{lccc}
\hline \multirow{2}{*}{ Larval } & \multicolumn{3}{c}{ Number of pupae obtained/cup } \\
\cline { 2 - 4 } Development & \multicolumn{3}{c}{ Population of larvae/cup } \\
\cline { 2 - 4 } & 25 & 20 & 15 \\
\hline
\end{tabular}

$$
\text { Dose }=1.0 \times 10^{7} \mathrm{PIB} / \mathrm{ml}^{1}
$$

$\begin{array}{llll}\begin{array}{l}\text { Beginning of } \\ \text { 4th instar } \\ \text { End of 4th }\end{array} & 0.1 \mathrm{c} \mathrm{B} & 0.8 \mathrm{c} \mathrm{AB} & 0.9 \mathrm{c} \mathrm{AB} \\ \begin{array}{l}\text { instar } \\ \text { Beginning of }\end{array} & 1.8 \mathrm{~b} \mathrm{C} & 2.9 \mathrm{~b} \mathrm{~B} & 4.6 \mathrm{~b} \mathrm{~A} \\ \begin{array}{l}5 \text { th instar } \\ \text { End of 5th } \\ \text { instar }\end{array} & 0.6 \mathrm{c} \mathrm{B} & 1.8 \mathrm{~b} \mathrm{~A} & 1.6 \mathrm{c} \mathrm{A} \\ & 8.3 \mathrm{a} \mathrm{A} & 6.1 \mathrm{a} \mathrm{B} & 6.5 \mathrm{a} \mathrm{AB}\end{array}$

Dose $=4.0 \times 10^{7} \mathrm{PIB} / \mathrm{ml}^{2}$

\begin{tabular}{lccc}
$\begin{array}{l}\text { Beginning of } \\
\text { 4th instar }\end{array}$ & 0.0 & 0.2 & 0.0 \\
$\begin{array}{l}\text { End of 4th } \\
\text { instar }\end{array}$ & 1.3 & 2.3 & 2.3 \\
$\begin{array}{l}\text { Beginning of } \\
\text { 5th instar }\end{array}$ & 0.3 & 0.6 & 0.8 \\
$\begin{array}{l}\text { End of 5th } \\
\text { instar }\end{array}$ & 3.4 & 4.4 & 3.8 \\
\hline
\end{tabular}

${ }^{1}$ Means followed by same lower case letter, in the columns, or by same upper case letter, the lines, are not different by the Duncan's test $(\mathrm{P} \leq 0.05)$. Coefficient of variation $(\mathrm{CV})$ was $16.2 \%$ for the lower dosage.

${ }^{2}$ For the higher dosage there was no homogeneity of variances.

varied from $2.7 \times 10^{10}(\mathrm{E} 5 \mathrm{~L})$ to $5.8 \times 10^{10} \mathrm{PIB} /$ cup (B5L), for the lower AgNPV dosage, and from $2.9 \times 10^{10}(\mathrm{~B} 4 \mathrm{~L})$ to $5.7 \times 10^{10} \mathrm{PIB} /$ cup (B5L), for the higher dosage. Mean PIB/larva increased from $1.4 \times 10^{9}$ (B4L) to $2.5 \times 10^{9}$ (B5L), decreasing for E5L $\left(2.2 \times 10^{9}\right)$. Furthermore, there was a trend of an increase in PIB/larva with the reduction in the initial larval density/cup, as can be drawn from the tables.

\section{Discussion}

The optimization of AgNPV productic was highly dependent on the studied varia, bles, specially larval size or instar at inoculation, or their interaction, as discussed for other viruses (Shapiro 1982,1986). Selecting insects by approximate size (experiment 1) was less efficient than by phase of larval development 
Table 7. Mean weight of NPV-dead larvae per 300-ml cup obtained after inoculation of Anticarsia gemmatalis larvae at four larval development stages and three populations per 300-ml cup, with two NPV dosages.

\begin{tabular}{|c|c|c|c|}
\hline \multirow{3}{*}{$\begin{array}{l}\text { Larval } \\
\text { Development }\end{array}$} & \multicolumn{3}{|c|}{ Weight of NPV-dead larvae (g)/cup } \\
\hline & \multicolumn{3}{|c|}{ Population of larvae/cup } \\
\hline & 25 & 20 & 15 \\
\hline & \multicolumn{3}{|c|}{ Dose $=1.0 \times 10^{7} \mathrm{PIB} / \mathrm{ml}^{1}$} \\
\hline $\begin{array}{l}\text { Beginning of } \\
\text { 4th instar }\end{array}$ & $2.28 \mathrm{bc} \mathrm{A}$ & $1.93 \mathrm{bc} \mathrm{AB}$ & $1.52 \mathrm{~b} \quad \mathrm{~B}$ \\
\hline $\begin{array}{l}\text { End of } 4 \text { th } \\
\text { instar }\end{array}$ & $2.58 \mathrm{~b} \mathrm{~A}$ & $2.18 \mathrm{~b} \mathrm{~A}$ & $1.66 \mathrm{~b} \quad \mathrm{~B}$ \\
\hline $\begin{array}{l}\text { Beginning of } \\
5 \text { th instar }\end{array}$ & 4.32 a $\mathrm{A}$ & $3.21 \mathrm{a} \mathrm{B}$ & 2.56 a C \\
\hline \multirow[t]{2}{*}{$\begin{array}{l}\text { End of } 5 \text { th } \\
\text { instar }\end{array}$} & $2.00 \mathrm{c} \mathrm{A}$ & $1.64 \mathrm{c} \mathrm{AB}$ & $1.23 \mathrm{~b} \mathrm{~B}$ \\
\hline & \multicolumn{3}{|c|}{ Dose $=4.0 \times 10^{7} \mathrm{PIB} / \mathrm{ml}^{1}$} \\
\hline $\begin{array}{l}\text { Beginning of } \\
\text { 4th instar }\end{array}$ & $2.14 \mathrm{c} \mathrm{A}$ & $1.63 \mathrm{c} \mathrm{B}$ & $1.74 \mathrm{bc} A B$ \\
\hline $\begin{array}{l}\text { End of 4th } \\
\text { instar }\end{array}$ & $3.21 \mathrm{~b} \mathrm{~A}$ & $2.89 \mathrm{~b} \mathrm{~A}$ & $2.18 \mathrm{ab} \mathrm{B}$ \\
\hline $\begin{array}{l}\text { Beginning of } \\
5 \text { th instar }\end{array}$ & $4.21 \mathrm{a} \mathrm{A}$ & 3.41 a B & 2.27 a $C$ \\
\hline $\begin{array}{l}\text { End of 5th } \\
\text { instar }\end{array}$ & $2.27 \mathrm{c} \mathrm{A}$ & $1.81 \mathrm{c} \mathrm{B}$ & $1.43 \mathrm{c} \mathrm{B}$ \\
\hline
\end{tabular}

${ }^{1}$ Means followed by same lower case letter, in the columns, or by same upper case letter, in the lines, are not different by the Duncan's test $(\mathrm{P} \leq 0.05)$. Coefficients of variation $(\mathrm{CV})$, from top to botton, were 14.6 and $15.0 \%$, respectively.

(experiment 2). In the former, the low NPV yields can be attributed to the difficulty in standardizing larvae at inoculation, resulting in higher canibalism and losses by other causes. However, the two experiments were not carried out simultaneously, such that the $A$. gemmatalis cohorts utilized might have been distinct enough (eg. vigour) to contribute for the substantial differences found between the two trials. However, it was evident that a better standardization of larvae was important to reduce losses in NPV production, since E4L and E5L (more difficult to standardize) resulted in higher losses in NPV production than B4L and B5L (selected during ecdysis).

The highest yield of AgNPV was achieved by inoculating B5L at 25 larvae/300-ml cup, either at $1.0 \times 10^{7}$ or $4.0 \times 10^{7} \mathrm{PIB} / \mathrm{ml}$. However, optimizing production by adjusting these and other parameters is variable with each spe- 
Table 8. Mean number of polyhedron inclusion bodies (PIB) of the NPV of Anticarsia gemmatalis obtained per 300-ml cup after inoculation of larvae at four phases of development and three populations per cup, with two NPV dosages.

\begin{tabular}{|c|c|c|c|}
\hline \multirow{3}{*}{$\begin{array}{l}\text { Larval } \\
\text { Development }\end{array}$} & \multicolumn{3}{|c|}{ Number of PIB $\times 10^{10} /$ cup } \\
\hline & \multicolumn{3}{|c|}{ Population of larvae/cup } \\
\hline & 25 & 20 & 15 \\
\hline & \multicolumn{3}{|c|}{ Dose $=1.0 \times 10^{7} \mathrm{PIB} / \mathrm{ml}^{1}$} \\
\hline $\begin{array}{l}\text { Beginning of } \\
\text { 4th instar }\end{array}$ & 3.09 & 2.61 & 2.06 \\
\hline $\begin{array}{l}\text { End of 4th } \\
\text { instar }\end{array}$ & 3.49 & 2.95 & 2.26 \\
\hline $\begin{array}{l}\text { Beginning of } \\
5 \text { th instar }\end{array}$ & 5.84 & 4.35 & 3.47 \\
\hline \multirow{2}{*}{$\begin{array}{l}\text { End of 5th } \\
\text { instar }\end{array}$} & 2.71 & 2.23 & 1.66 \\
\hline & \multicolumn{3}{|c|}{ Dose $=4.0 \times 10^{7} \mathrm{PIB} / \mathrm{ml}^{2}$} \\
\hline $\begin{array}{l}\text { Beginning of } \\
\text { 4th instar }\end{array}$ & $2.90 \mathrm{c} \mathrm{A}$ & $2.20 \mathrm{c} \mathrm{B}$ & $2.36 \mathrm{bc} \mathrm{AB}$ \\
\hline $\begin{array}{l}\text { End of 4th } \\
\text { instar }\end{array}$ & $4.34 \mathrm{~b} \mathrm{~A}$ & $3.91 \mathrm{~b} \mathrm{~A}$ & $2.95 \mathrm{ab} B$ \\
\hline $\begin{array}{l}\text { Beginning of } \\
5 \text { th instar }\end{array}$ & 5.70 a $\mathrm{A}$ & $4.61 \mathrm{a} \mathrm{B}$ & 3.06 a C \\
\hline $\begin{array}{l}\text { End of } 5 \text { th } \\
\text { instar }\end{array}$ & $3.08 \mathrm{c} \mathrm{A}$ & $2.44 \mathrm{c} \mathrm{B}$ & $1.94 \mathrm{c} \mathrm{B}$ \\
\hline
\end{tabular}

${ }^{1}$ For the lower dosage there was no homogeneity of variances.

${ }^{2}$ Means followed by same lower case letter, in the columns, or by same upper case letter, in the lines, are not different by the Duncan's test $(\mathrm{P}<0.05)$. Coefficient of variation $(\mathrm{CV})$ was $14.9 \%$ for the higher dosage.

cific host, virus isolate, and laboratory conditions (Shapiro 1986). for the NPV of Heliothis (Helicoverpa) spp., maximum production was attained by inoculating five-day-old larvae (Shieh \& Bohmfalk 1980). In contrast, Shapiro et al. (1981) reported that larvae infected in late instars produced more virus than those infected in early instars. This was also observed by Harper (1970) with Peridroma saucia
(Hbn.) infected in mid 5th instar, by Huber \& Dickler (1977) with Rhyacionia buoliana (Schif.) inoculated as late 4th or early 5th instar, and by Shapiro (1986) with $L$. díspar inoculated as 5th instar.

These differences regarding the moment of inoculation for distinct virus-host systems are probably related to the virus dosage and larval density/recipient utilized in each test. 
The virus concentration used has varied from $1.0 \times 10^{5}$ to $5.0 \times 10^{7} \mathrm{PIB} / \mathrm{ml}$ (Shapiro 1986), with a greater initial concentration not necessarily resulting in greater virus yield (Shapiro et al. 1981). In the present work, highest AgNPV yields were obtained by infecting larvae with high dosages $\left(1.0 \times 10^{7}-4.0 \times 10^{7} \mathrm{PIB} / \mathrm{ml}\right)$. As observed with the AgNPV, studies with other baculoviruses show a trend of lower yields of PIB/larva for increasing larval populations/ recipient (Shapiro 1986). For L. dispar, as larval density increased from 10 to 14/recipient the number of PIB/larva decreased, and total NPV yield/container became constant (Shapiro 1986). Similarly, total yield of Trichoplusia ni (Hübner) NPV increased as larval density increased from 100 to 400/recipient, although the number of PIB/larva decreased by threefold (Vail et al. 1881). With the A. gemmatalis NPV, highest yields were achieved by using 25 larvae/300-ml cup as opposed to 20 and 15 larvae/cup, despite an increase in PIB/larvae at lower larval densities.

The results show that AgNPV production can be much improved, so as to allow its commercial production and utilization at a competitive cost with available chemical insecticides. However, the material and methods used in this study have to be tested in a larger scale to check their feasibility at industry level. Parra et al.(1993) developed a new method for large-scale rearing of A. gemmatalis and proposed the procedure for AgNPV production. The combination of this method with the information generated in the present study may prove useful for commercial production of the AgNPV

\section{Literature Cited}

Federici, B.A. 1990. Bright horizons for invertebrate pathology, p.v-ix. In Proceedings of the Int. Colloquium Invertebr. Pathol. Microb. Control, 5, Adelaide, Soc. Invertebr. Pathol., 547p.
Greene, G.L., N.C. Leppia \&W.A. Dickerson. 1976. Velvetbean caterpillar: a rearing procedure and artificial medium. J. Econ. Entomol. 69:487-488.

Harper, J.D. 1970. Laboratory production of Peridroma saucia and its nuclear polyhedrosis virus. J. Econ. Entomol. 63: 1633-1634.

Hoffmann-Campo, C. B., E. B. de Oliveira \& F. Moscardi. 1985. Criação massal da lagarta da soja (Anticarsia gemmatalis). EMBRAPA-Centro Nacional de Pesquisa de Soja, Londrina, Documentos 10,21 p.

Huber, J. 1986. Use of baculoviruses in pest management programs, p. 181 -202. In R.R. Granados \& B.A. Federici (eds.), The biology of baculoviruses, vol. 2. Boca Raton, CRC Press, 276p.

Huber, J. 1990. History of the CpGV as a biological control agent-its long way to a commercial viral pesticide, p.424-427. In Int. Colloquium Invertebr. Pathol. Microb. Control, 5, Adelaide, Soc. Invertebr. Pathol., 547p.

Huber, J. \& E. Dickler. 1977. Codling moth granulosis virus: its efficiency in the field in comparison with organophosphorus insecticides. J. Econ. Entomol. 70:557-561.

Ignoffo,C.M.1966. Insect viruses, p.501-530. In C.N. Smith (ed.), Insect colonization and mass production. New York, AcademicPress,618p.

Ignoffo C. M. \& T. L. Couch. 1981. The nucleopolyhedrosis virus of Heliothis species as a microbial insecticide, p.329-362. In H. D. Burges (ed.), Microbial control of pests and plant diseases 1970-1980. London, Academic Press, 949p. 
Moscardi, F. 1986. Utilização de vírus para o controle da lagarta da soja, Anticarsia gemmatalis, p. 188-202. In S.B.Alves (ed.), Controle microbiano de insetos. São Paulo, Manole, 407p.

Moscardi, F. 1989. Use of viruses for pest control in Brazil: the case of the nuclear polyhedrosis virus of the soybean caterpiliar, Anticarsia gemmatalis. Mem. Inst. Oswaldo Cruz 84: 51-56.

Moscardi, F. 1990. Development and use of soybean caterpiliar baculovirus in Brazil, p. 184-187. In Int. Colloquium Invertebr. Pathol. Microb. Control, 5, Adelaide, Soc. Invertebr. Pathol.,547p.

Moscardi, F. \& D. R. Sosa-Gómez. 1992. Use of viruses against soybean caterpillars in Brazil, p.98-109. In L. G. Copping, M. B. Green \& R.T. Rees (eds.), Pest management in soybean. London, Elsevier Appiied Science, 369p.

Moscardi, F. \& D.R. Sosa-Gómez. 1993. A case study in biological control: soybean defoliating caterpiliars in Brazil, p. 115-119. In D. R. Buxton, R. Shibles, R. A. Forsberg, B. L. Blad, K. H. Asay, G. M. Paulsen \& R. F. Wilson (eds.), International Crop Science I. Madison, Crop Sci. Soc. of America Inc., 895p.

Parra, J. R. R, P. S. M. Botelho, S.B.Alves \& E. A. Magrini. 1993. Controle biológico da lagarta-da-soja Anticarsia gemma- talis: projeto piloto para produção de Baculovirus anticarsia, visando ao seu controle. ESALQ/USP, Piracicaba, Bol. Tec.3,10p.

Shapiro, M. 1982. In vivo mass production of insect viruses for use as pesticides, p.463492. In E. Kurstak (ed.), Microbial and viral pesticides. New York, Marcel Dekker, 720 p.

Shapiro, M. 1986. In vivo production of baculoviruses,p.31-61.In R. R. Granados \& B. A. Federici (eds.), The biology of baculoviruses, vol. 2. Boca Raton, CRC Press, 276p.

Shapiro, M., C. D. Owens, R. A. Bell \& H. A. Wood. 1981. Simplified, efficient system for in vivo production of the gypsy moth nucleopolyhedrosis virus. J. Econ. Entomol. 74:341-343.

Shieh,T.R. 1989. Industrial virus production. Adv. Virus Res. 36: 315-343.

Shieh, T.T. \& G.T. Bomfalk. 1980. Production and efficacy of baculoviruses. Biotechnol. Bioengin. 22:1357.

Vail, P. V., S.J. Anderson \& D.L. Jay. 1973. New procedures for rearing cabbage loopers and other lepidopterous larvae for propagation of nuclear polyhedrosis viruses. Environ. Entomol. 2: 339-344.

Received 21/VII/95. Accepted 12/11/97. 